Broken Harp Strings: The Art Songs of Kyrylo Stetsenko and the Ukrainian Art Song Project

Author(s): Melanie Turgeon

Source: Kyiv-Mohyla Humanities Journal 4 (2017): 85-93

Published by: National University of Kyiv-Mohyla Academy

http://kmhj.ukma.edu.ua/ 


\title{
Broken Harp Strings: The Art Songs of Kyrylo Stetsenko and the Ukrainian Art Song Project
}

\author{
Melanie Turgeon \\ The King's University, Edmonton (Canada)
}

\begin{abstract}
The art song genre began in Ukraine with Mykola Lysenko. Lysenko's student, Kyrylo Stetsenko, followed his teacher's example and composed 42 art songs, that are marked by desolation, anguish, and repression, yet with occasional strong glimpses of hope and love. Repressive political circumstances, which Stetsenko desperately fought to change, and various life events as a composer and Orthodox priest truly resulted in the heartfelt music that he wrote. Subsequent Ukrainian composers also wrote art songs despite prohibition of the Ukrainian language in print, in performance, and in scores. Over the past decade, thanks to the diligent efforts of the Ukrainian Art Song Project, the world stage is being introduced to hundreds of forbidden art songs by Ukrainian composers. Founded in 2004 by world-renowned bass-baritone, Pavlo Hunka, the Ukrainian Art Song Project aims to record, publish, promote and perform the art songs of more than 26 eminent Ukrainian composers by 2025 .
\end{abstract}

Key Words: Art Song, Kyrylo Stetsenko, Ems Ukase, Pavlo Hunka, Ukrainian Art Song Project, Mykola Lysenko, Ukrainian National Republic, Oleksandr Koshyts, Ukrainian Republican Kapelle.

\section{Introduction}

Ukrainian composer Kyrylo Stetsenko (1882-1922) is known for his contribution to the genre of choral music; additionally, the past decade has revealed his talents as an art song composer. In 2006 the Ukrainian Art Song Project published and released his 42 art songs. Stetsenko was a composer, conductor, music critic, teacher, community activist, and Orthodox priest. ${ }^{1}$ He deeply cared for his country and the welfare of its people; thus, he played an active role in the Ukrainian National Republic. There is no doubt that his inherent desire to improve conditions in Ukraine, and later his political affiliation, truly influenced his art songs. The art song genre allowed him a medium through which he could express his challenges and experiences. Resilience during hardship is a prominent theme in Stetsenko's art songs; in essence it summarizes how he walked the path he was given and how he lived his life. Wasyl Sydorenko perfectly expresses the following:

$1 \quad$ Wasyl Wytwycky, "Stetsenko, Kyrylo," in Internet Encyclopedia of Ukraine, accessed February 8, 2017, http://www.encyclopediaofukraine.com/display. asp?linkpath=pages $\%{ }_{5} \mathrm{CS} \%{ }_{5} \mathrm{CT} \%{ }_{5} \mathrm{CStetsenkoKyrylo.htm.}$ 
Joy and sorrow embrace the art songs of Kyrylo Stetsenko. Tsarist repression, revolution, censorship, exile and war are their companions. Only a free spirit like Stetsenko could survive the times and create songs of unsurpassed beauty, inner strength and delicate intimacy. The songs display a stunning array of changing emotions - from impassioned patriotism, bitter irony and cruel disappointment, to hopeful yearning, ardent love and peaceful reflection. There are moments of epic timelessness, mystic invocation, heroic struggle and domestic bliss. These are songs that express Ukraine's poetic soul through the universal language of music. ${ }^{2}$

\section{The Art Song Genre and Its Prohibition in Ukraine}

The art song genre began in the early 19th century in Western Europe most notably with Franz Schubert (1797-1828) in Germany. It flourished in various European countries over the course of that century, and commenced in Ukraine decades later with the national composer, Mykola Lysenko (1842-1912). Unquestionably, the productivity of the art song in Ukraine was stifled by two significant political events: The Ems Ukase ${ }^{3}$ and the Bolshevik Revolution. The Ems Ukase was a decree issued in 1876 by Tsar Alexander II of Russia, banning the use of the Ukrainian language in print, in performance, and in scores. Thus, Ukrainian composers were forced to break the law in order to write art songs. ${ }^{4}$

The second political event that significantly suppressed the art song was the Bolshevik Revolution. From a musical perspective, the Bolshevik Revolution brought with it strong support for propaganda music. Music with words, namely vocal and choral music, was most encouraged since it had the potential of indoctrinating the nation. Consequently, the most popular choral genres were the oratorio, cantata, and what the Russians termed "massovaia pesnia" (mass song). In the words of Boris Schwarz, "recognizing the political usefulness of these genres, the government subsidized the writing and publishing of 'revolutionary' music." ${ }^{5}$

Higher art forms, like the art song, were labeled formalist, aristocratic or bourgeois. Moreover, the fact that the art song was a Western European genre transported to the East, also contributed to its undesirability. The Soviet regime also censored all music prior to publication or performance in order to ensure its nationalistic and socialist qualities. Yet, despite these exceedingly restrictive conditions, Ukrainian poets still wrote poems and Ukrainian composers still put these poems to music, resulting in many art songs created "for the drawer." It is remarkable how many art songs were being composed given these restrictions. Thankfully, composers found ways to conceal this artistic output, and in more recent years we have begun to discern what truly exists.

Wasyl Sydorenko, "Kyrylo Stetsenko (1882-1922)," liner notes, Kyrylo Stetsenko: The Art Songs (CUOA 2006), 5 .

3 The decree was named after the German city Bad Ems, since this is where it became official.

4 Wasyl Sydorenko, "Ukrainian Art Songs," liner notes, Kyrylo Stetsenko: The Art Songs (CUOA 2006), 2.

5 Boris Schwarz, Music and Musical Life in Soviet Russia: 1917-1981, enlarged ed. (Bloomington: Indiana University Press, 1983), 32-33. 


\section{Lysenko and a National Movement in Composition}

Mykola Lysenko was a musical pioneer, particularly in his utilization of folk materials, and encouragement of ethnomusicological endeavors. He wanted his students and colleagues to make use of folk songs, to "work with them, and be inspired by them, to appreciate their beauty not only as a part of the past, but also as vital though fragile elements of a contemporary tradition." ${ }^{\prime}$ Mykola Lysenko (1842-1912), Oleksandr Koshyts (1875-1944), Mykola Leontovych (1877-1921), and Kyrylo Stetsenko (1882-1922) definitely contributed to a national movement in Ukrainian composition, which involved the creative use of folk materials. These individuals caused the emergence of a "new school" of national music. They tried to do for Ukraine what they witnessed in other "national" composers like Smetana and Dvorak.

In 1899, while in seminary, Stetsenko became acquainted with Lysenko. He was his student, as well as a singer in his choir, and his assistant conductor. Lysenko mentored Stetsenko and introduced him to several significant poets and musicians. He once commented to his colleagues: "This is who will replace me after my death."7 Unquestionably, Lysenko had much confidence in and respect for his young student.

\section{Stetsenko's Journey}

The succession of events in Stetsenko's life, and the upheaval and unrest in Ukraine in the early 2oth century, definitely impacted him and influenced the music he wrote. When Kyrylo was merely ten years old his uncle, Danylo Horyanskyi, took him to Kyiv where he was enrolled in St. Sophia Church School. He attended this school for five years from 1892-1897, and lived with his uncle throughout this time, only returning home to his parents for the summers. Kyrylo was the eighth child in a family of eleven children, and undoubtedly his family struggled financially. When Kyrylo would return home from school for the summers he would work hard and earn money to purchase clothing for himself. ${ }^{8}$ Stetsenko hailed from religious roots: his father was an iconographer and his maternal grandfather an Orthodox priest. ${ }^{9}$

Young Kyrylo definitely had talent. Within three years of attending St. Sophia, he became the choir conductor at age 13 and also wrote his first composition. After his time at St. Sophia's School, in 1897, Kyrylo entered the Kyiv Theological Academy and Seminary. He attended the seminary from 1897 until 1903. During these seminary years he composed several of his works for choir.

Stetsenko desired to establish an independent music publishing house; however, for various political reasons this did not come to fruition. In 1907, his ambitious actions led to him being

6 Taras Filenko and Tamara Bulat, The World of Mykola Lysenko: Ethnic Identity, Music, and Politics in Nineteenth and Early Twentieth Century Ukraine (Edmonton: Ukraine Millennium Foundation, 2001), 143 .

7 “Kyrylo Stetsenko," Wikipedia, accessed February 15, 2017, https://en.wikipedia.org/wiki/Kyrylo_ Stetsenko.

8 "Kyrylo Stetsenko," Wikipedia.

9 Sydorenko, "Kyrylo Stetsenko (1882-1922)," 5 . 
arrested and exiled out of Kyiv to a town in the Donbas. There he taught music from 1907-1910.10 Ultimately, in 1911, Stetsenko surrendered to the pressures of his uncle, and he was ordained a Ukrainian Orthodox priest. It is difficult to know if he truly felt called to join the priesthood, or if this decision was somewhat influenced by a desire to experience increased financial security. "Financial security, however, came at a price. The composer was required to serve in an obscure village in south-western Ukraine, far from the cultural life of Kyiv. There, in his self-imposed exile, Stetsenko weathered the political storm of WWI."11

When the Russian Revolution began in 1917, Stetsenko felt the need to return to Kyiv. At this time the Ukrainian National Republic was founded and Stetsenko became the head of the Music section of the Ministry of Education. Together with Oleksandr Koshyts, Stetsenko formed the Ukrainian Republican Kapelle. Stetsenko led one group of singers that toured Ukraine to promote national unity, while the choir led by Koshyts toured beyond Ukraine to propagate Ukrainian music and culture. ${ }^{12}$

The new Communist government disbanded the choirs in 1920, when the Bolsheviks took over Ukraine. In Warsaw, Koshyts reorganized the Ukrainian Republican Kapelle into the Ukrainian National Choir in 1920. Thereafter their touring of Europe and the Americas resumed and they continued their mission of promoting the Ukrainian National Republic. By the time the group disbanded in 1924, they had performed approximately goo concerts! These concerts were inconceivably well attended; for example, an audience of over 32 ,ooo people were present in Mexico City on December 26, 1922. ${ }^{13}$

While Koshyts was outside the borders of Ukraine pursuing these very ambitious and popular concert tours, Stetsenko was once again forced out of Kyiv in 1920, and he continued his priestly ministry in the village of Vepryk. Being in rural Ukraine did not stop Stetsenko from passionately persevering to better his country. In 1921, he cofounded the Ukrainian Autocephalous Orthodox Church. He also founded a theatre and a choir in Vepryk. Stetsenko's initiative and hard work abruptly ceased in the spring of 1922 . While ministering to the sick in the village, Stetsenko contracted typhus and died at the age of 39 .

\section{Stetsenko's Compositional Output, Legacy, and the Establishment of the Ukrainian Art Song Project}

Despite his untimely death, Stetsenko still left behind a legacy of compositions. He wrote music for several genres including a variety of choral works, 42 art songs, music for stage works including plays, children's operas, and two additional incomplete operas. ${ }^{14}$ His two most prolific genres are the art song, and choral music. Like Lysenko, Stetsenko made a noteworthy contribution

$10 \quad$ Wytwycky, "Stetsenko, Kyrylo."

11 Sydorenko, "Kyrylo Stetsenko (1882-1922)," 5 .

12 Sydorenko, "Kyrylo Stetsenko (1882-1922)," 5 .

13 Wasyl Wytwycky, “Ukrainian Republican Kapelle," Internet Encyclopedia of Ukraine

(Originally printed in Encyclopedia of Ukraine, vol. 5, 1993), accessed February 12, 2017, www. encyclopediaofukraine.com/display.asp?linkpath=pages $\backslash \mathrm{U} \backslash \mathrm{K} \backslash$ UkrainianRepublicanKapelle.htm. 
to the art song genre; however, he did not afford the same volume as Lysenko, who wrote 124. Stetsenko wrote well over 100 choral works including two Divine Liturgies, a Panakhyda, both accompanied and a cappella choruses, carols, cantatas, and several folk song arrangements. Stetsenko wrote some of his most significant works months before his passing. This included a Panakhyda dedicated to the memory of his teacher and mentor, Mykola Lysenko. ${ }^{15}$

In the 1950s musicologists started publishing collections of Ukrainian classical music, yet these editions were strongly academic and they did not facilitate or encourage performance of this music.16 In 2004, the Ukrainian Art Song Project (UASP) was founded; thus, only within the past thirteen years has the world been introduced to the art songs of Lysenko, Stetsenko, among other noteworthy Ukrainian composers, through recordings and live performances. The driving force behind it is renowned British bass-baritone, Pavlo Hunka. Born to a Ukrainian father and an English mother, Hunka first studied Modern Languages and practiced as a lawyer before embarking on his vocal studies at the Royal Northern College of Music in the U. K. He commenced his vocal career at the Basel Opera Company in Switzerland. ${ }^{17}$ Ever since, Hunka has maintained an incredibly successful opera career. Together with Canada's leading opera stars, Hunka has already recorded and released 16 CDs of Ukrainian art songs.

Despite the fact that Lysenko predates Stetsenko, Kyrylo Stetsenko: The Art Songs was the first recording project embarked on by the UASP. It was released in September 2006. The sheer volume of Lysenko's art songs surely influenced the UASP to start with Stetsenko, a project onethird the size and far more manageable as an inaugural event. As Hunka explains: "Stetsenko was my first choice to record as he is an accessible-to-all composer; very melodic, equal in piano and voice, extremely expressive and he chose very clear and direct texts." ${ }^{18}$ Stetsenko almost exclusively utilized the poetry of Ukrainians, such as Oleksandr Oles, Taras Shevchenko, Lesia Ukrainka, Borys Hrinchenko, among others. Themes of Stetsenko's art songs include: social and political injustice, nature, love (quite often unfulfilled love), suffering, exile, despair, various folk themes, and particularly hope and resilience during hardship.

Resilience during hardship is a sincerely prominent theme among Stetsenko's art songs. Knowing the various challenges he lived through, and his ambitious actions towards improved political times in Ukraine, it is not surprising that this theme had such prominence. Porvalysia struny (Broken Harp Strings) is likely the last art song Stetsenko wrote and in so many ways this song encapsulates a true veracity in Stetsenko's life. "This song was composed during the Ukrainian Civil War of 1920. The spirit is undaunted but the harp strings are broken. Nevertheless, both poet and composer press onwards with hope." The English translation of Oles's poetry aptly captures how desolate the situation is, yet how the Ukrainian people, led by a very passionate and patriotic Stetsenko, still press on with courage and optimism: "The strings on the harp have broken and the silenced harp mourns..." The song transitions into major for the final stanza: "Laughing, joking, singing. I don't bemoan my fate. As I pluck the broken strings of my heart." 19

15 Wytwycky, "Ukrainian Republican Kapelle.”

16 Sydorenko, "Kyrylo Stetsenko (1882-1922)," 5.

17 "Pavlo Hunka" (Internet ed.), accessed February 3, 2017, https://www.ukrainianartsong.ca/newpage-3.

18 Pavlo Hunka, e-mail message to author, January 17, 2017.

19 Liner notes to the CD, Kyrylo Stetsenko: The Art Songs (CUOA 2006), 22. 
The most recognized art song Stetsenko wrote is Vechirnia pisnia (Evensong). This song gained its popularity when it served as the sign off tune, concluding each day of broadcasting for Ukraine's State Radio. ${ }^{20}$ Suitably, the song describes the setting sun. The text consists of three verses and Stetsenko sets it in strophic form.

\section{The Road Beyond Lysenko and Stetsenko}

The Ukrainian Art Song Project has accomplished so much since the original Stetsenko project. After successfully completing this two-disc set they embarked on the monumental Lysenko recording. It took six CDs to archive his 124 songs. Following Stetsenko and Lysenko the UASP continued with Yakiv Stepovyi (1883-1921). Very similar to Stetsenko, Stepovyi wrote two CDs worth of songs, 55 in total. "Stepovyi was one of the first modern Ukrainian composers to avoid the direct use of folk material. He sought to transform the traditional language of music into a new modernist idiom and thus create a new national identity." 21

After Stepovyi came the Galician projects. Presently Galicians I: The Art Songs has been released and Galicians II has been recorded but not yet released. These two Galician projects have definitely witnessed several composers with much variety. Galicians I consists of 81 songs recorded onto six CDs, including 16 songs by late-romantic Denys Sichynskyi (1865-1909); 28 songs by post-romantic Stanislav Liudkevych (1879-1979); 17 songs by post-romantic and impressionist Vasyl Barvinskyi (1888-1963); and 20 songs by the modernist Stefania Turkewich (1898-1977). ${ }^{22}$

Very unfortunate circumstances surrounded Vasyl Barvinskyi. In 1948 Barvinskyi was exiled to a labor camp by the Soviets. All of his compositions were publically burned. He returned to Lviv a decade later, regrettably, a completely broken and desolate man. The final five years of his life were spent trying to recall and recreate his compositions. ${ }^{23}$

Of particular mention on the Galicians I CD set is Ukraine's first female composer, Stefania Turkewich. Stefania studied with Barvinsky, among several others, even including the music revolutionary, Arnold Schoenberg, in Berlin. It is difficult to imagine how challenging it must have been for a female composer to succeed in early-to-mid 2oth century Ukraine. Turkewich's ability to study composition with numerous individuals and furthermore obtain a doctorate in musicology from Charles University in Prague, is truly remarkable. Turkewich managed to finally flee from the Soviets in 1946, when she immigrated to England with her second husband. ${ }^{24}$ It is difficult to describe Turkewich's style, needless to say that it is comparably more modern than the styles of those who preceded her. Sydorenko describes her art songs as follows: "When they are not post-romantic, atonal, or expressionistic in character, her compositions are stylistically much more modern yet still hark back to Ukrainian folk songs." 25

20

Kyrylo Stetsenko: The Art Songs, 34.

Wasyl Sydorenko, "Yakiv Stepovyi (1883-1921)," liner notes, Yakiv Stepovyi: The Art Songs (UMSA 2010$), 7$.

Wasyl Sydorenko, "The European Connection," liner notes, Galicians I: The Art Songs (CUOA 2014),

8-9.

Sydorenko, "The European Connection," 9.

Sydorenko, "The European Connection," 9.

Sydorenko, "The European Connection," 9. 


\section{The Three Phases of the Ukrainian Art Song Project}

The Ukrainian Art Song Project has insistently maintained a very high standard. In addition to Pavlo Hunka assembling a number of Canada's renowned opera stars, all pianists and instrumentalists are also highly successful, distinguished professional artists. Every facet of the project is of the topmost quality. All recording thus far has been done at the Glenn Gould Studio in Toronto. Moreover, the CD booklets are extremely comprehensive and informative. In addition to the biographical information of the composers and artists, there is a thorough musicological writeup. All song lyrics and information contained in the CD booklet is included in four languages: English, Ukrainian, French, and German. This definitely supports the anticipated outreach and distribution of this project and speaks to the value of the music.

To date, the Ukrainian Art Song Project has recorded $35^{2}$ songs. Recording the music is merely the first phase of this project. The second phase of the UASP is called the world-wide library, and it includes the actual printed music or score. There is a definite conscientiousness to ensure this music is widely available and accessible. All scores that have been recorded and released can be downloaded for free on the UASP website. ${ }^{26}$ Moreover, they can be transposed into any key, plus the text is printed in Cyrillic and also transliterated, along with a thorough pronunciation guide. Since all scores are in the public domain, they are not copyrighted and can be duplicated, distributed, and performed.

The third and final stage of the Ukrainian Art Song Project entails performing and promoting this music. This involves visiting various Schools or Faculties of Music and Music Conservatories, in order to expose students to this vast amount of vocal repertoire that exists. Pavlo and other artists have already performed at various universities, conservatories, festivals, and conferences. This summer the UASP is hosting its first Summer Institute in Toronto from August 7-13, 2017. This includes an "intensive immersion into Ukrainian art songs — the language, poetic realm, musical style, socio-historical context and performance practice — culminating in a final recital for the public." 27

Technology and social media, networking, and overall promotion and publicity have made it possible for news about this project to travel to many Ukrainian families who have Ukrainian art songs in their possession. So far, 1,161 Ukrainian art songs have been collected. Pavlo predicts: "I guess that there will be 2000 by the end ... if we live that long." ${ }^{28}$ The intention and ambition is to record and publish the art songs of more than 26 eminent Ukrainian composers such as Mykola Dremliukha, Lesia Dychko, Mykola Fomenko, Petro Haidamaka, Dmytro Klebaniv, Borys Liatoshynskyi, Heorhii Maiboroda, Yulii Meitus, Myroslav Skoryk, Ihor Sonevytskyi, Valentyn

26 Occasionally various upgrades are done and a specific composer's music may appear to be unavailable. Simply contact the UASP (info@ukrainianartsong.ca) to inquire about obtaining the music you desire. “Summer Institute" (Internet ed.), accessed May 15, 2017, https://www.ukrainianartsong.ca/newpage-2.

28 Pavlo Hunka, e-mail message to author, January 17, 2017. 
Sylvestrov, among several others, and in addition to those who have already been recorded. ${ }^{29}$ The ultimate goal is to have everything recorded by 2025 !

\section{From the Drawer to the World Stage}

The poets and composers who collaboratively produced these Ukrainian art songs definitely took a chance when they created the poetry and music that merged to become the countless art songs Ukraine can now celebrate and take pride in. Beginning in the mid-187os and continuing for a substantial part of the 2oth century, composers had to break the law to write this music. Thankfully they had the courage, determination, and bravery to compose this music "for the drawer." They had the strength and drive to adapt to the adverse conditions imposed upon them. Resilience during hardship is such a prominent theme in Stetsenko's art songs, and it truthfully describes how he lived his life. Unquestionably, this theme continued in the minds and hearts of subsequent Ukrainian art song composers, and consequently we have music of immense beauty produced from sincere emotion and inner strength.

The founder of the Ukrainian Art Song Project, Pavlo Hunka, aptly proclaimed how "this music deserves to be on the world stage," and thanks to his tireless determination and incredible talent, together with the bravery and unwavering artistic perseverance of Lysenko, Stetsenko, and those who succeeded them, we have hundreds of art songs to share. May the resilience of the UASP artists and committee continue, and the generosity of donors not subside so that this monumental project may one day come to complete fruition. We have been granted this opportunity to utilize the present and the future to expose and promote what was forbidden and prohibited from thriving in the past. Let this music that was created "for the drawer" now rightfully occupy its entitled position on the world stage.

\section{Bibliography}

Fedotov, Yevhen Serhiiovych. Kyrylo Hryhorovych Stetsenko - Pedahoh [Kyrylo Hryhorovych Stetsenko — the Pedagog]. Kyiv: Muzychna Ukraina, 1977.

Filenko, Taras, and Tamara Bulat. The World of Mykola Lysenko: Ethnic Identity, Music, and Politics in Nineteenth and Early Twentieth Century Ukraine. Edmonton: Ukraine Millennium Foundation, 2001.

Horiukhina, N. and L. Yefremova. K. H. Stetsenko [K. H. Stetsenko]. Kyiv: Mystetstvo, 1955.

Kyrylo Stetsenko: The Art Songs, liner notes. Canadian Ukrainian Opera Association (2 disc set), 2006.

Lisetskyi, S. Rysy styliu tvorchosti K. Stetsenka [Features of the Style of K. Stetsenko's Creative Works]. Kyiv: Muzychna Ukraiyina, 1977.

Mykola Lysenko: The Art Songs, liner notes. Canadian Ukrainian Opera Association (6 disc set), 2010.

29 "What Is an Art Song? How Does It Differ from a Folk Song?" (Internet ed.), accessed February 11, 2017, https://www.ukrainianartsong.ca/what-is-an-art-song/. 
Parkhomenko, L. O. Kyrylo Hryhorovych Stetsenko [Kyrylo Hryhorovych Stetsenko]. Kyiv: Muzychna Ukraina, 1973.

Schwarz, Boris. Music and Musical Life in Soviet Russia: 1917-1981. Enlarged ed. Bloomington: Indiana University Press, 1983.

Sydorenko, Wasyl. "Kyrylo Stetsenko (1882-1922)," liner notes, Kyrylo Stetsenko: The Art Songs. Canadian Ukrainian Opera Association (2 disc set), 2006.

Sydorenko, Wasyl. "The European Connection," liner notes, Galicians I: The Art Songs. Canadian Ukrainian Opera Association (6 disc set), 2014.

Sydorenko, Wasyl. "Ukrainian Art Songs," liner notes, Kyrylo Stetsenko: The Art Songs. Canadian Ukrainian Opera Association (2 disc set), 2006.

Sydorenko, Wasyl. "Yakiv Stepovyi (1883-1921)," liner notes, Yakiv Steporyi:The Art Songs. Ukrainian Music Society of Alberta (2 disc set), 2010.

Turgeon, Melanie. Composing the Sacred in Soviet and Post-Soviet Russia: History and Christianity in Alfred Schnittke's Concerto for Choir. Saarbrücken, Germany: VDM Verlag Dr. Müller, 2008.

Wytwycky, Wasyl. "Stetsenko, Kyrylo." Internet Encyclopedia of Ukraine. Accessed February 8, 2017. http://www.encyclopediaofukraine.com/display.asp?linkpath=pages\%5 CS\%5CT\%5CStetsenkoKyrylo.htm.

Wytwycky, Wasyl. "Ukrainian Republican Kapelle." In Internet Encyclopedia of Ukraine, originally printed in Encyclopedia of Ukraine, vol. 5, 1993. Accessed February 12, 2017. www.encyclopediaofukraine.com/display.asp?linkpath=pages $\backslash U \backslash K \backslash U k$ rainianRepublican Kapelle.htm.

\section{(7)}

Melanie Turgeon is Associate Professor of Music and Choral Director at The King's University in Edmonton, Alberta. She has conducted numerous choirs and ensembles and has presented research at several academic institutions and conferences both in Canada and internationally. She has toured extensively with her choirs, including two very successful European tours, and has gained national recognition with her Slavic Chamber Choir, Kappella Kyrie. In addition to her role at King's, Dr. Turgeon is a member of the Eparchial Liturgical Commission, where she is responsible for the incorporation of liturgical music and texts into various publications for the Ukrainian Catholic Church. Since 2002, she has served as Music Director and Cantor at St. Josaphat Ukrainian Catholic Cathedral in Edmonton. Highlights in her research endeavors include the publication of a book entitled Composing the Sacred in Soviet and Post-Soviet Russia (2008); a hymnal with an accompanying five-CD set, Sing to our God (2008); three recordings with Herurymy Ukrainian Female Quartet; and one with King's Choirs, entitled, The Voice of My Prayer (2011). Dr. Turgeon's most recent research undertaking is Ukrainian Voices: Music of a Nation. Through performances, recordings, scholarship, and publications, Ukrainian Voices brings awareness, knowledge, and accessibility to the music of various cherished and celebrated Ukrainian composers from the 17th to the early 19th century. Melanie has been involved with the Ukrainian Art Song Project for several years and she is most excited to serve on the faculty for Summer Institute 2017 ! 